\title{
The Determinant of Earning Quality Using State Ownership as Moderating Variable on Companies in Malaysia
}

\author{
Retnoningrum Hidayah ${ }^{1^{*}}$, Ahwan Sholih ${ }^{2}$, Linda Agustina ${ }^{3}$, Rita Rahayu ${ }^{4}$ \\ ${ }^{123}$ Fakultas Ekonomi Universitas Negeri Semarang, Indonesia

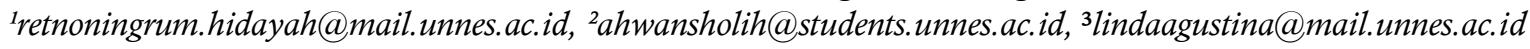 \\ ${ }^{4}$ ritarahayu@eb.unand.ac.id *corresponding authors
}

\begin{abstract}
The study aims to determine the effect of disclosure of corporate social responsibility (CSRD), dividend policy, and audit committee financial expertise (ACFE) on earnings quality. It uses state ownership as a moderating variable. The population consists of government-linked companies (GLCs) and transportation and logistics sector companies listed on the Malaysia Stock Exchange for the period 2016-2019 by employing a purposive sampling method. The research analysis applies Moderate Regression Analysis (MRA) with the SPSS program. The results showed that CSRD has a positive effect on earnings quality. Meanwhile, dividend policy has a negative effect on earnings quality. Further, state ownership strengthens the relationship between dividend policy and earnings quality. However, ACFE does not affect earnings quality. At last, the moderating effect of government ownership variables is not significant to the relationship between CSRD and earnings quality.
\end{abstract}

Keywords: CSR disclosure, dividend policy, ACFE, earnings quality, state ownership

\section{Faktor Penentu Kualitas Laba Dengan Kepemilikan Negara Sebagai Variabel Moderating Pada Perusahaan di Malaysia}

\begin{abstract}
Abstrak
Penelitian bertujuan untuk mengetahui pengaruh pengungkapan corporate social responsibility (CSRD), kebijakan deviden (dividend policy), dan keahlian keuangan komite audit (ACFE) terhadap kualitas laba (earning quality). Lebih lanjut, penelitian ini menggunakan kepemilikan pemerintah (state ownership) sebagai variabel moderating. Populasi penelitian terdiri dari government-linked companies (GLCs) dan perusahaan sektor transportasi serta logistik yang terdaftar di Malaysia Stock Exchange periode 2016-2019. Pemilihan sampel menerapkan metode purposive sampling. Analisis penelitian menggunakan Moderate Regression Analysis (MRA) dengan program SPSS. Hasil penelitian menunjukkan CSRD berpengaruh secara positif terhadap kualitas laba. Kebijakan deviden memiliki pengaruh secara negatif terhadap kualitas laba. Selanjutnya, state ownership memperkuat hubungan kebijakan deviden dan kualitas laba. Namun, ACFE tidak mampu memberikan pengaruh terhadap kualitas laba. Selanjutnya, pengaruh moderasi variabel kepemilikan pemerintah tidak signikan terhadap hubungan antara CSRD terhadap kualitas laba.
\end{abstract}

Kata kunci: pengungkapan CSR, kebijakan deviden, ACFE, kualitas laba, kepemilikan negara

\section{INTRODUCTION}

Financial Accounting Standard Board (FASB) in Financial Accounting Concepts (SFAC) No. 1, elaborates that the high quality of earnings an entity has is able to guarantee the existence of a more complete range of company financial performance features that are useful for decision making (Mousa \& Desoky, 2019). Earnings quality is an indicator of the quality of the company's financial reporting performance (Baioco, 2016). The authors develop measures for earnings quality to reflect the effects of accounting risk, incentive variations and managers' information. Several studies support that the persistence, 
predictability, value relevance, and quality of accruals are closely related to their earnings quality measures. Managers have the authority to make decisions that can affect net income. Through the flexibility of the accrual system, managers can have the opportunity to make accrual adjustments by adjusting the current reported income (Mousa \& Desoky, 2019). Thus, the quality of earnings, which was originally able to offer guidance for stakeholders in decision making, can no longer be used as a reference. This is contradictory to ideal conditions where the theory states that profit can be used as a reference for stakeholders. Factually, it cannot be as a reference making it as a gap phenomenon.

The existence of accrual adjustments has implications for the company's financial condition is doubted. This has caused financial information becomes detrimental to investors due to fraud. Fraud that occurs in companies around the world is closely related to earnings quality such as overstatement, mark-ups, and manipulation of financial statements. A study of major corporate cases including Lucent, Enron, Toshiba Corp. and others, resulted in a low level of earnings quality making this detrimental to policy makers, especially investors. The level of earnings quality in Malaysia can be seen at a macro level regarding how high the implementation of fraudulent financial statements is. The implementation of corruption in Malaysia is still a problem to be aware of especially for academics such as research purposes. Corruption cases that occur are inseparable from the implementation of fraud by individuals in companies and governments. Global Economic Crime and Fraud Survey 2018 in Malaysia Report conducted by PricewaterhouseCoopers in Malaysia report that $41 \%$ of all companies experienced economic crime in the last two years (Pricewaterhouse Coopers, 2018).

In 2018, the MISC company provided full support to the Malaysian Anti-Corruption Commission (MACC) to investigate allegations of power abuse, corruption and fraudulent payment claims involving an estimated RM109 million (Malaymail, 2018). MACC launched an investigation with information on alleged bribery in the form of fraudulent claims made between MISC officials and maritime contractors. The parties reportedly filed claims to receive payment for ship maintenance services. In fact, no maintenance was carried out from 2010 to 2013. In February 2018, MACC visited the company office and confiscated several documents of the investigation (Energy, 2018).

Research on earnings quality has been conducted by several researchers in various countries (Al-dhamari \& Ku Ismail, 2015; Egbunike \& Odum, 2018; Hartini, 2017; Hoang, Abeysekera, \& Ma, 2019; Mulchandani, Mulchandani, \& Wasan, 2019; Salehi \& Bahrami, 2017). This study empirically examines the level of earnings quality in various company sectors. A study carried out by Egbunike \& Odum (2018) examining earnings quality in Nigeria, found that the components of the independent board including the audit committee financial expertise (ACFE), became an indicator of earnings quality with its role as supervisor of financial statements. There was a research by Nguyen \& Bui (2019) having an empirical test of dividend policy on earnings quality in Vietnam. Vietnam is a country that has an unstable dividend policy and lower earnings quality reporting than developed markets. The results show that dividend policy is an indicator of 
earnings quality. This study presents a new nuance by empirically examining earnings quality in Malaysia with a focus on the transportation and logistics sectors as well as Government-linked Companies for the period 2016-2019.

The practice of corporate social responsibility disclosure (CSRD) has grown worldwide. Malaysia is one of the countries taking advantage of this momentum. Bursa Malaysia provided voluntary guidance on CSRD to its members in 2006 and then made CSRD mandatory for all public companies which took effect on 31 December 2007. The government also made CSRD a requirement for listing companies on the stock, including its subsidiaries (Mamun et al., 2017). Agency theory states that companies try to reduce the problems by being socially and socially responsible. Research conducted by Siueia \& Wang (2019) shows that CSRD has a significant effect in a negative direction on earnings quality. This is contrary to research conducted by Rezaee, Dou, \& Zhang (2019) and Mohmed, Flynn, \& Grey (2019) that CSRD has a significant positive effect on earnings quality.

Signaling theory explains that dividend payments made by companies serve as a profitable signal to the capital market. Dividend policy is a signaling device that can be used by management to convey information about a company's prospects to investors. Several studies that have explained with data on developed and developing markets have resulted that earnings quality in dividend-paying companies is higher than earnings quality in non-dividend-paying companies (Nguyen \& Bui, 2019). However, the existence of a high dividend policy also does not guarantee good earnings quality. Malaysia Company Law: Principles and Practices 2017 which updated the Companies Act 1965 and Companies Act 2016 in section B11 regarding Changes to Dividend Rules states that dividends can be paid by the company from the profit available if the company is able to pay its debts (solvent) (Scholar, 2015). Several studies which support that dividend policy have a positive effect on earnings quality include Nguyen \& Bui (2019); Salehi \& Bahrami (2017); Deng, Li, \& Liao (2017); and Mulchandani, Mulchandani, \& Wasan (2019). Meanwhile, research by Mousa \& Desoky (2019) illustrates that dividend policy has no effect on earnings quality. Meanwhile, Sulastri, Adel, \& Manik (2016) suggest that changes in the dividend rate have a negative effect on earnings quality.

The company's financial statements are also confirmed by the party that directly ensures the quality of financial information, namely the audit committee. Audit committee financial expertise (ACFE) is the most prominent feature in assessing the effectiveness of the audit committee. Agency theory also explains that the existence of an audit committee can reduce agency costs borne by shareholders (Bilal, Chen, \& Komal, 2018). The Sarbanes-oxley Act (SOX) explains that the definition of a financial expert includes accounting expertise and non-accounting financial expertise (Baioco, 2016). The documented requirement says that the company has at least three independent audit committees. One of them must have financial expertise in charge of overseeing financial reporting (Bursa Malaysia, 2018). Research that supports ACFE has an effect on earnings quality, including Bilal et al., (2018); Primtasurbakti et al. (2017); and Baioco (2016). 
Meanwhile, research by Egbunike \& Odum (2018) mentions that ACFE as a component of the board leadership structure has a negative effect on earnings quality.

Malaysia ranks fifth highest in the world in terms of countries having the highest SOEs presence among their largest companies. Deng et al. (2017) investigated the moderating effect of state ownership and found evidence that state ownership weakens the impact of dividend payments on earnings quality. The stakeholder theory also explains that the government is one of the policy makers who can influence all operational activities through regulation. Various studies have been conducted that $20 \%$ share ownership by the government becomes the minimum effective measure as companies are said to be GLCs in Malaysia (Hartini, 2017).Therefore the research focuses on analyzing the effect of corporate social responsibility (CSRD), dividend policy, and audit committee finance (ACFE) on earning quality. The uniqueness of this research is first, the addition of state ownership variables as moderating variables in the relationship between CSRD and dividend policy on earnings quality. Second, this study uses a sample of governmentlinked companies (GLCs) and transportation and logistics sector companies listed on the Malaysia Stock Exchange for the 2016-2019 period, which are still rarely studied.

Mohmed et al. (2019) explain that there is some empirical evidence that companies that are active in CSRD policies provide higher quality earnings and are less involved in earnings management. Companies active in CSR activities are able to reveal earnings quality with a higher index and a lower level of discretionary accruals. Several studies have stated that there is a positive relationship between CSRD and earnings quality in various company sectors. CSRD is positively related to the reliability of the accrual component, and has a negative relationship in the earnings game. Malaysia is a country that makes disclosure of corporate social responsibility a mandatory policy. This policy has been established since December 31, 2007 stating it is a must for companies to carry out their responsibilities ethically to the community (Mamun et al., 2017). With this mandatory policy, CSRD is believed to have a strong influence on earnings quality. Based on the perspective of stewardship theory, managers can try to improve the company's financial position, especially for long-term goals. The hypothesis in this study refers to Mohmed et al. (2019); Aziz \& Faisol (2018); Hutapea (2019); and Obeng, Ahmed, \& Miglani (2020).

$\mathrm{H}_{1}$ : Corporate social responsibility disclosure has a significant positive effect on earnings quality.

According to Nguyen \& Bui (2019), dividends illustrate information about company earnings such as an increase or a decrease in profits. When a company stops distributing its profits to interested parties, this becomes an information signal about the condition of the company. Dividend policy can be applied as a market perception of a company's future earnings prospects. Malaysia is a developing country that pays attention to dividend policy for investors. Based on the research of Sulastri et al. (2016) found that changes in the dividend rate have a negative effect on earnings quality. This indicates that the higher the dividend fluctuation, the lower the earnings quality. In other words, a company that decreases and then increases its dividend is an indication that the quality of earnings has 
decreased. This is an implication of the dividend return rate on stock prices (dividend yield) from several years of company reports. The hypothesis of this study refers to Sulastri et al. (2016); Pathak \& Ranajee (2020); and Faradi \& Supriyanto (2019).

$\mathrm{H}_{2}$ : Dividend policy has a significant negative effect on earnings quality.

The number or composition of the audit committee in a company is considered important for the effective monitoring activities of all these committees. Corporate governance in Malaysia, especially the third party, regulates the obligation of companies to have at least three audit committees consisting of an independent boards. One of them must be a financial expert as a committee in charge of overseeing financial reporting (Bursa Malaysia, 2018). Several studies have found mixed results regarding the relationship between audit committee financial expertise (ACFE) and earnings quality. Bilal et al. (2018) found that ACFE (audit committee financial expertise) has a positive effect on earnings quality. In line with the results of this study, applying the statement that companies that have ACFE can lead to a higher level of earnings quality. The general expectation is that the audit committee will be more expert in conducting supervision because it is able to better understand the financial reporting process. ACFE is also believed to be able to effectively monitor and limit management activities to manipulate revenue. This hypothesis refers to Bilal et al. (2018); Primtasurbakti et al. (2017); and Baioco (2016).

$\mathrm{H}_{3}$ : Audit committee financial expertise (ACFE) has a significant positive effect on earnings quality.

In agency theory, the government participated in control and share, has the role of appointing the board of commissioners to influence company policy through the selected board of commissioners. Thus, the supervision of the quality of company earnings can be improved (Hartini, 2017). A minimum $20 \%$ share ownership as a company classified as GLCs causes the government to have influence on all policies including corporate social responsibility as a factor of earnings quality. A study conducted by Rezaee et al. (2019), resulted that state-owned enterprises (SOEs) have more resources to engage in CSR activities and more incentive to disclose their CSR performance than non-SOEs. The effectiveness of CSRD policy initiatives can also be influenced by differences in state institutions, including market development policies and legal infrastructure from local governments. Further, Rezaee et al. (2019) also confirms that state ownership moderates the effect of CSRD in company activities on earnings quality.

$\mathrm{H}_{4}$ : Government ownership moderates the positive influence of corporate social responsibility disclosure on earnings quality

Deng et al. (2017) stated that state ownership or the private sector will affect the relationship between dividend policy and earnings quality. A minimum of $20 \%$ controlling share ownership for the government opens the opportunity for the government to control company policy (Hartini, 2017). One of them is the dividend policy which is believed to be a factor in earnings quality as mentioned in the principle of positive signals for investors in the signaling theory. Further, according to Mousa \& Desoky (2019), there are several arguments from the study which reveal that companies with state ownership use 
dividends as an instrument to explore company resources. Research shows that state shareholders prefer cash dividends over stock dividends. Thus, dividend payments made by the company affect the quality of earnings in the company's financial years. The implication is that the power of dividends to influence earnings quality is different in companies with state ownership status (Deng et al., 2017).

$\mathrm{H}_{5}$ : Government ownership moderates the negative effect of dividend policy on earnings quality.

\section{METHOD}

Research sample is taken from a selected population by certain procedures (Wahyudin, 2015). This study involves companies in the government-linked companies (GLCs), and the transportation \& logistics sector with the observation year during the 2016-2019 period employing 121 units of company analysis in the Malaysia Stock Exchange.

The dependent variable employed is earnings quality. This is an indicator of financial reporting quality which can be simplified by using earnings persistence. Earnings quality is based on the relative difference in accrual persistence to cash flow (Nguyen \& Bui, 2019). This variable is measured by the formula used in previous research (Givoly, Hayn, \& Katz, 2010; and Surifah, 2010):

$$
O I_{i t}=a+\beta_{1} C F_{i t}+\beta_{2} A C C R_{i t}+\varepsilon_{i t}
$$

Furthermore, the independent variables consists of disclosure of corporate social responsibility (CSRD), dividend policy (dividend policy), financial expertise of the audit committee (ACFE). Disclosure Corporate social responsibility disclosure (CSRD) is the overall individual category of a company's CSR activities which includes four components including the environment; community; employees and products (Siueia \& Wang, 2019). To measure, the variable employs a Dummy Variable through CSR Scores. Based on 4 categories, namely environment; community; employees and products, the company is given a score from 0-4. If the company reports the four components, it is assessed as 4 , while the value of 0 is for companies that do not report any of CSR components (Branco \& Rodrigues, 2006; Siueia \& Wang, 2019).

The financial expertise of the audit committee (ACFE) is independent boards taking role to oversee the process of preparing a company's financial reporting with a minimum number of three members. ACFE can be measured using the amount of ACFE in the company (Bilal et al., 2018). The measurement of this variable focuses on the large number of audit committees who already have financial expertise but are not limited to public accountants in the company. This is in accordance with the Sarbanes Oxley Act that ACFE includes other financial skills such as risk management, investment analysts and others (Bilal et al., 2018).

Next, the moderating variable is state ownership. State ownership is a company that has a government ownership status measured by dummy variables (Rezaee et al., 2019). The dummy variable is that the company gets a value of 1 if there is government 
ownership and 0 if the company does not have government share ownership (Deng et al., 2017; Rezaee et al., 2019).

Further, hypothesis testing is a method of decision making in a research that based on data analysis. This study employs the SPSS tool. A test where moderating variable exists, it can use Moderated Regression Analysis (MRA). MRA is an analytical approach to determine the role of moderating variables and maintain sample integrity. To the MRA, the test of the relationship between the independent and moderated variables on the dependent variable through equations can be applied. There are two independent variables assumed to be influenced by moderating variables. Hence, it requires five regression equations as follows:
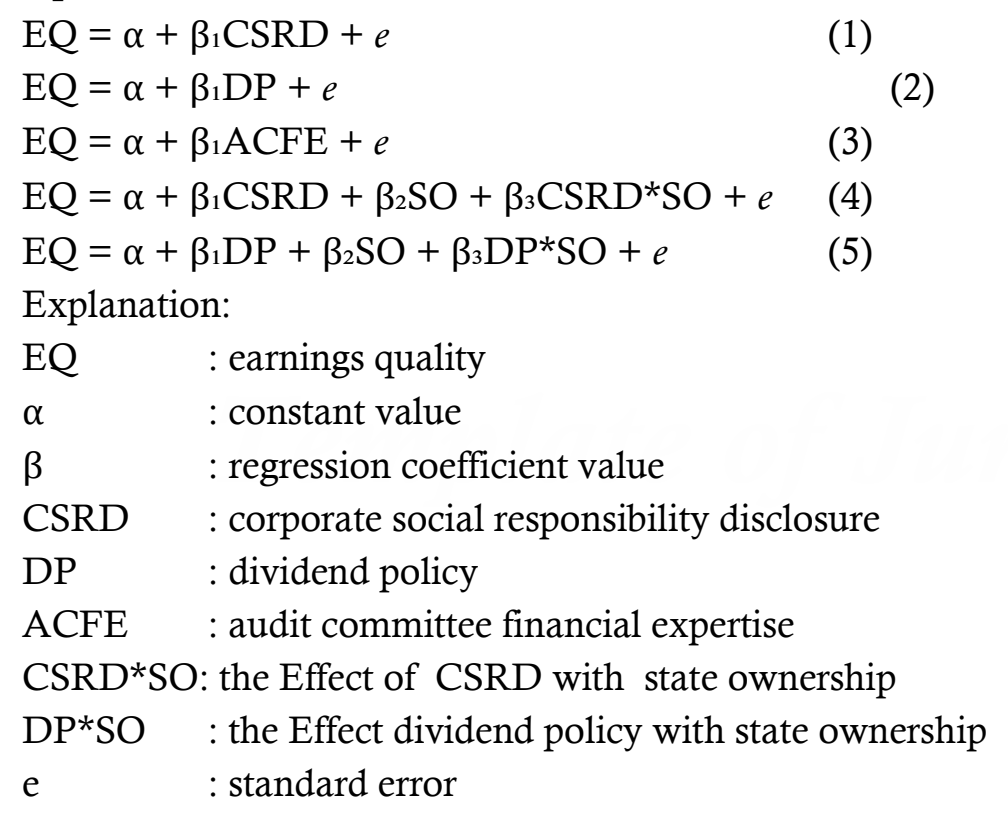

The moderation effect test has a role in determining the magnitude of the strength of the moderating variable to provide a reinforcing or weakening effect on the influence of the independent variables, namely CSRD, dividend policy and ACFE on the dependent variable which is earnings quality. If the significance value of the effect of the interaction of the independent and moderating variables on the dependent variable is $<0.05$, this means it can provide a moderating role on the relationship of the independent and dependent variables. This study applies pure moderator because the moderating variable does not function as an independent variable. 


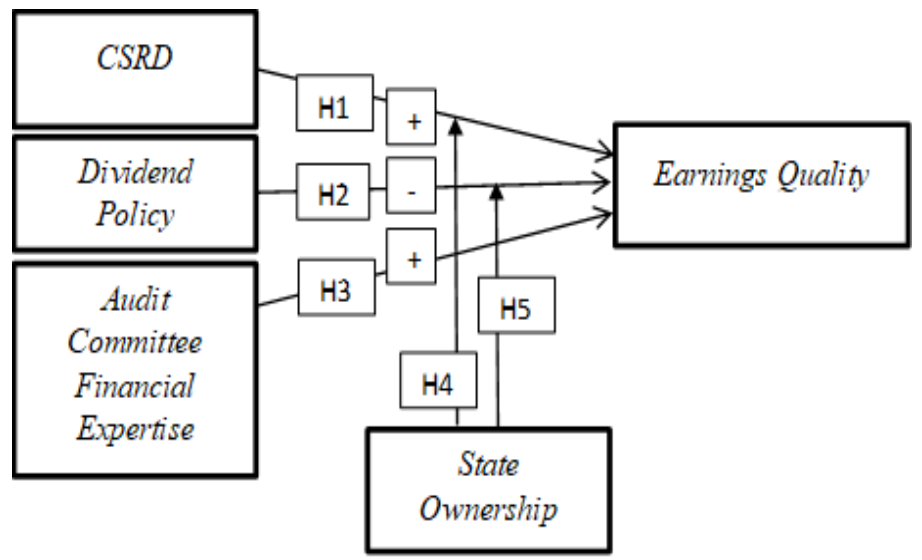

Figure 1. Research Model

\section{FINDING AND DISCUSSION}

Descriptive analysis illustrates an overview of the research data. This analysis provides an overview regarding the variable disclosure of corporate social responsibility (CSRD), dividend policy (DP), audit committee (ACFE) which includes minimum, maximum, mean / average and standard deviation values (Table 1).

Table 1. Descriptive Analysis Results

\begin{tabular}{cccccc}
\hline Variable & $\mathrm{N}$ & Minimum & Maksimum & Mean & Std. Deviation \\
\hline CSRD & 121 & 1 & 4 & 3,6550 & 0,61826 \\
DP & 121 & 0,00 & 4,14 & 1,1971 & 0,59319 \\
ACFE & 121 & 2 & 9 & 4,28 & 1,473 \\
\hline
\end{tabular}

Next, the classical assumption test is carried out. Based on the classical assumption test, it proves that the data is normally distributed and there is no autocorrelation. Also, there is no multicollinearity and is free from heteroscedasticity.

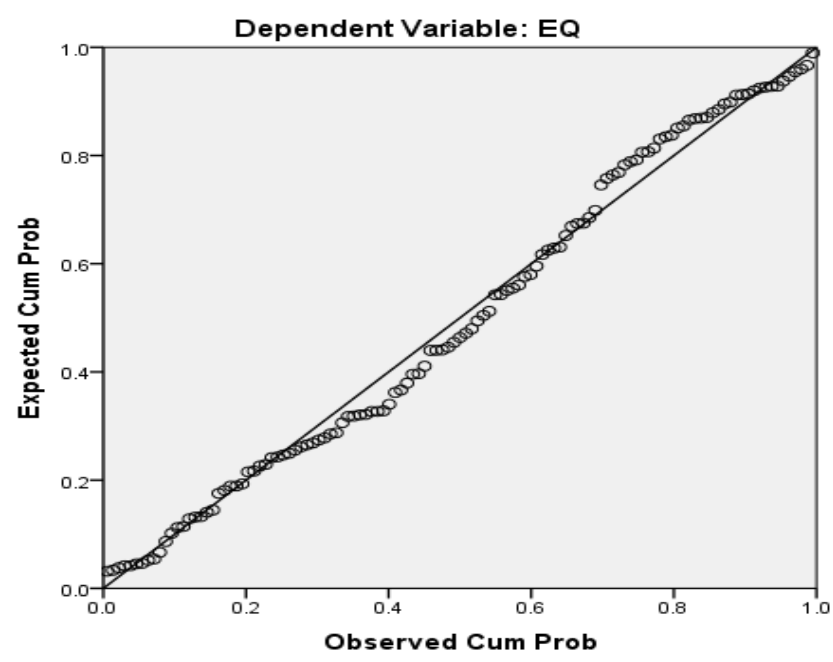

Figure 2. Graph of Normal P-Plot Regression Standardized Residual

Source: Data from SPSS analysis, 2020 
Figure 2 is the data distribution showing it is around the line and follows the direction of the diagonal line. This implies that the data are normally distributed. Then, Table 2 illustrates the results of the tolerance values for no variables that have tolerance values less than 0.10. Meanwhile, if viewed through the VIF value table, none of the research variables obtained a VIF value of more than 10, either CSRD, DP, ACFE and SO. Thus, the research is free from multicollinearity.

Table 2. Multicollinearity Test Results

\begin{tabular}{lccl}
\hline Variable & Tolerance & VIF & Conclusion \\
\hline CSRD & 0,661 & 1,512 & Free from multicollinearity \\
DP & 0,819 & 1,222 & Free from multicollinearity \\
ACFE & 0,786 & 1,272 & Free from multicollinearity \\
SO & 0,669 & 1,494 & Free from multicollinearity \\
\hline
\end{tabular}

Table 3 shows the Durbin-Watson value of 2.176. This value will then be compared with the DW Table, both the DU (Durbin Upper) value and the DL (Durbin Lower) value with a significance of $5 \%$. Based on the number of independent variables $4(\mathrm{~K}=4)$, the upper limit value (du) is 1.75438 , while the lower limit value (dl) is 1.65290 . Then the DW value of 2.176 is more than the value of $\mathrm{dU}$ and $\mathrm{dL}$. This confirms that it is free from positive autocorrelation. Meanwhile, the $4-\mathrm{dw}$ value is 1.824 , which means it is more than the upper limit (du) and lower limit (dl) meaning there is no negative autocorrelation.

Table 3. Durbin-Watson Autocorrelation Test

\begin{tabular}{cccccc}
\hline Model & $\mathrm{D}-\mathrm{W}$ & $\mathrm{d}_{\mathrm{L}}$ & $\mathrm{d}_{\mathrm{U}}$ & $4-\mathrm{d}_{\mathrm{U}}$ & Keterangan \\
\hline Nilai & 2,176 & 1,65290 & 1,75438 & 1,824 & Free from autocorrelation \\
\hline
\end{tabular}

Figure 3 illustrates the scatterplot graph to test heteroscedasticity showing the distribution of points randomly. These points are not in the form of any pattern either below the number 0 on the $\mathrm{Y}$ axis. From the results of this analysis, the regression model in this study is free from heteroscedasticity.

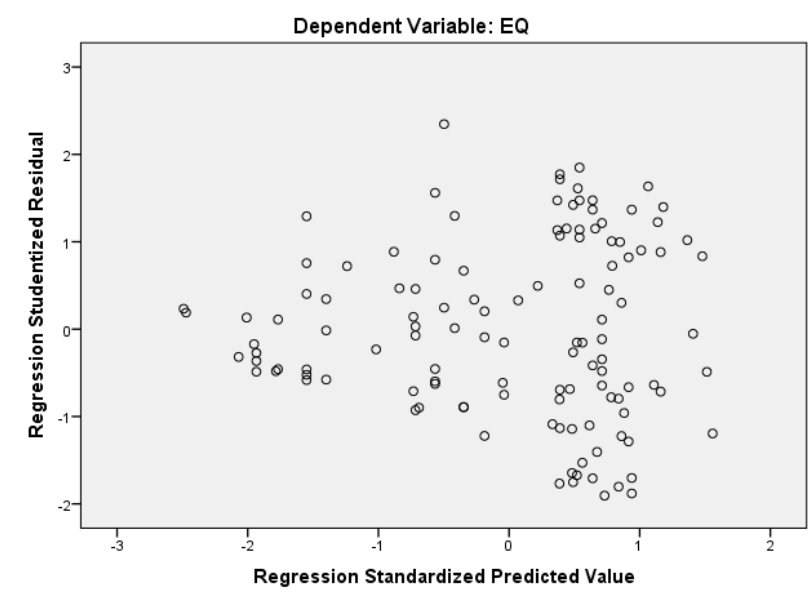

Figure 3. Scatterplot Graph

Source: Secondary data processed by the author, 2020

Table 4 illustrates the results of the hypothesis test. It reveals the significance value of $\mathrm{H} 1$ is 0.011 which is less than 0.05 . Thus, $\mathrm{H} 1$ is accepted. Table 2 indicates that CSRD 
has a positive coefficient value of 0.445 . Therefore, the first hypothesis is accepted, namely CSRD has a significant positive effect on earnings quality. This is in accordance with previous research (Aziz \& Faisol, 2018; Hutapea, 2019; Mohmed et al., 2019; Obeng et al., 2020). Mohmed et al. (2019) stated that there is some empirical evidence that companies that are active in CSRD policies offer higher earnings quality. Companies that are active in CSR activities are able to reveal higher earnings quality and have a lower level of discretionary accruals. Several studies noted that there is a positive relationship between CSRD and earnings quality in various corporate sectors. CSRD is positively related to the reliability of the accrual component, and has a negative relationship in the earnings game. Thus, the companies that are actively involved with CSRD are believed to have good accrual measurements.

Table 4. Hypothesis Testing Results

\begin{tabular}{ccccc}
\hline & Variable & B Value & Sig. Value & Result \\
\hline & (Constant Value) & $-0,179$ & 0,492 & \\
H1 & CSRD & 0,445 & 0,011 & accepted \\
H2 & DP & $-0,141$ & 0,015 & accepted \\
H3 & ACFE & 0,028 & 0,237 & rejected \\
H4 & CSRD*SO $^{*}$ SO & 0,055 & 0,288 & rejected \\
H5 & DP*SO $^{*}$ & 0,187 & 0,000 & accepted \\
\hline
\end{tabular}

Furthermore, the H2 test results show a significance value of 0.015 less than 0.05 , meaning that $\mathrm{H} 2$ is accepted. The value of the partial significance test resulted the dividend policy's a coefficient value of -0.141 which means that there is a negative effect. This confirms the study result from Sulastri et al. (2016); Faradi \& Supriyanto (2019); and Pathak \& Ranajee (2020). According to Sulastri et al. (2016); the changes in the dividend rate have a negative effect on earnings quality, which means that the higher the dividend fluctuation, the lower the earnings quality. This indicates that companies which decrease and then increase their dividends show a signal of decreasing earnings quality. This implies the dividend return rate on stock prices (dividend yield) from several years of company reports. If the company consistently increases dividends, the quality of earnings will increase or vice versa. If the percentage of dividends to share price is high but it is not in accordance with the condition of the financial statements, then there is an indication of poor earnings quality. This has been also confirmed by Pathak \& Ranajee (2020) saying that the dividend policy will further reduce the quality of earnings if the company manipulates earnings.

However, the H3 test shows a significance value of $0.237(>0.05)$. This made H3 rejected. This result is supported by several previous studies (Bajra \& Čadež, 2018; Budianto, Samrotun, \& Suhendro, 2018; Dewi, Endiana, \& Arizona, 2020; Majiyebo, Okpanachi, Nyor, Adabenege, \& Ahmed, 2018; Samosir, 2018; and Wulandari, 2018) who also confirmed that the audit committee including ACFE did not have any influence on earnings quality. Bajra and Čadež (2018) mention that the competence possessed by $\mathrm{ACFE}$ and its effectiveness in implementing supervision greatly affects the results of 
ACFE performance tos ensure that financial reporting is in accordance with procedures and rules. An audit committee that does not have high competence results in weak controls making the fraud cannot be detected properly causing a huge problem in the next few years. The ineffectiveness of the implementation of duties and responsibilities by ACFE which is not optimal can also cause the failure of the supervisory process in the preparation of financial reports. Some studies also state that the reason ACFE has no effect on earnings quality is weak corporate governance. Thus, the existence of an audit committee is not an important factor for earnings quality.

The $\mathrm{H} 4$ test resulted a significance value of 0.288 which means that state ownership failed to be a moderating variable for the effect of CSRD on earnings quality (H4 is rejected). As stated by Hoang, Abeysekera, \& Ma (2019) and Choi, Lee, \& Park (2013) that state \& foreign ownership are not able to moderate the implementation of CSR on earnings quality. This study also fails to confirm the relationship between state ownership rules and the effect of CSRD on earnings quality. Minimum $20 \%$ share ownership as a company classified as GLCs causes the government to have influence on all policies including corporate social responsibility as a factor of earnings quality (Hartini, 2017). Legitimacy theory confirms that CSRD is an effort a company can take to offer something back to stakeholders (society) causing the people's perceptions and expectations about company improved. In addition, the social contract theory explains that the existence of the community is a major influence in the company's business continuity process. Because the company exists to provide benefits to the community. Thus, within the scope of the discussion on CSRD, the community becomes a strong stakeholder in the CSRD reporting process. This has caused the presence of the state not to carry a great deal of importance in terms of CSRD. Another reason is also caused by the CSRD policy in Malaysia. A study conducted by Rezaee et al. (2019) shows that the effectiveness of CSRD policy initiatives can also be influenced by differences in state institutions including market development policies and legal infrastructure from local governments. State ownership cannot moderate the effect of CSRD on earnings quality because CRSD has been a mandatory since 2007. This means there is no significant difference between GLCs and non-GLCs companies in implementing CSRD.

$\mathrm{H} 5$ test indicates a significance value of 0.000 meaning that state ownership is able to moderate the negative effect of dividend policy on earnings quality. Hence, H5 is accepted. This study is in accordance with Deng et al. (2017), that state ownership or the private sector will affect the relationship between dividend policy and earnings quality. Research shows that state shareholders prefer cash dividends over stock dividends (Mulchandani et al., 2019). This has caused the dividend payments affect the quality of earnings in the company's financial years (Mousa \& Desoky, 2019). This implies that the power of dividends to influence earnings quality is different in companies with state ownership status (Deng et al., 2017). Companies with state ownership status affect the negative role of dividends, which is proxied by dividend yield on earnings quality. Therefore, companies that pay their dividends in a high fluctuating manner will cause lower earnings quality, especially in government-owned companies. In the sample of this 
study, there are several companies, especially those that have state ownership (GLCs) having quite fluctuating dividend yields.

\section{CONCLUSION}

The result of the tests illustrates that corporate social responsibility disclosure (CSRD) offers a positive effect on earnings quality. Then, dividend policy has a significant negative effect on earnings quality. Meanwhile, Audit Committee Financial Expertise (ACFE) has no effect on earnings quality. Further, state ownership is not able to moderate the relationship between corporate social responsibility disclosure and earnings quality. However, state ownership manages to moderate the negative effect of dividend policy on earnings quality in government-linked companies (GLCs) and the transportation \& logistics sector on the Bursa Malaysia for the 2016-2019 period. This study only limits to a sample of companies government-linked companies (GLCs) and the transportation \& logistics sector in Bursa Malaysia for the period 2016-2019.

This study implies that based on the perspective of stewardship theory, CSR disclosure can increase the credibility making the quality of profits will be even better. Meanwhile, from a signaling theory point of view, it shows that dividend policy can provide positive signals to investors about earnings quality. Therefore, companies need to pay serious attention to disclosure of corporate social responsibility to improve their performance. However, this study only employed a limited sample of government-linked companies (GLCs) and companies in the transportation \& logistics sector in Bursa Malaysia for the period 2016-2019. Hence, it could be necessary to expand the sample in other sectors or based on the stock index with a research period of more than four years to generalize.

\section{REFERENCES}

Al-dhamari, R., \& Ku Ismail, K. N. (2015). Cash holdings, political connections, and earnings quality: Some evidence from Malaysia. International Journal of Managerial Finance, 11(2), 215-231. https://doi.org/10.1108/IJMF-02-2014-0016.

Aziz, A. J., \& Faisol, D. A. (2018). Pengaruh Corporate Social Responsibility Terhadap Kualitas Laba (Studi Empiris Pada Perusahaan-Perusahaan Selain Industri Keuangan Yang Terdaftar Di Bei). Jurnal Akunida, 4(1), 1. https://doi.org/10.30997/jakd.v4i1.1384.

Baioco, V. G. (2016). Effects of the audit committee and the fiscal council on earnings quality in Brazil *. USP, São Paulo, 28(November 2015), 229-248. https://doi.org/10.1590/1808-057x201703250.

Bajra, U., \& Čadež, S. (2018). Audit committees and financial reporting quality: The 8th EU Company Law Directive perspective. Economic Systems, 42(1), 151-163. https://doi.org/10.1016/j.ecosys.2017.03.002.

Bilal, Chen, S., \& Komal, B. (2018). Audit committee financial expertise and earnings quality: A meta-analysis. Journal of Business Research, 84(November 2017), 253-270. 
https://doi.org/10.1016/j.jbusres.2017.11.048.

Branco, M. C., \& Rodrigues, L. L. (2006). Corporate social responsibility and resourcebased perspectives. Journal of Business Ethics, 69(2), 111-132. https://doi.org/10.1007/s10551-006-9071-z.

Budianto, R., Samrotun, Y. C., \& Suhendro. (2018). Pengaruh Good Corporate Governance (GCG) terhadap Kualitas Laba pada Perusahaan Manufaktur yang Terdaftar di BEI 2015-2017. Prosiding Seminar Nasional: Manajemen, Akuntansi, Dan Perbankan, 1(1), 411-424. http://conferences.uinmalang.ac.id/index.php/semnasfe/article/view/731.

Bursa Malaysia. (2018). Chapter 15 - Corporate Governance. https://www.bursamalaysia.com/sites/5bb54be15f36ca0af339077a/content_entry5c e3b50239fba2627b2864be/5ce3b5ce5b711a163beae1bd/files/MAIN_Chap15_Anticorruption_1June2020.pdf?1590748016.

Choi, B. B., Lee, D., \& Park, Y. (2013). Corporate social responsibility, corporate governance and earnings quality: Evidence from Korea. Corporate Governance: An International Review, 21(5), 447-467. https://doi.org/10.1111/corg.12033.

Deng, L., Li, S., \& Liao, M. (2017). Dividends and earnings quality: Evidence from China. International Review of Economics and Finance, 48, 255-268. https://doi.org/10.1016/j.iref.2016.12.011.

Dewi, I. G. A. S., Endiana, I. D. M., \& Arizona, P. E. (2020). Pengaruh Leverage, Investment Opportunity Set (Ios), Dan Mekanisme Good Corporate Covernance Terhadap Kualitas Laba Pada Perusahaan Manufaktur Di Bursa Efek Indonesia. Jurnal Kharisma, 21(1), 1-9. https://doi.org/10.1016/j.solener.2019.02.027.

Egbunike, C. F., \& Odum, A. N. (2018). Board leadership structure and earnings quality. Asian Journal of Accounting Research, 3(1), 82-111. https://doi.org/10.1108/ajar-052018-0002.

Energy, O. (2018). Malaysia Starts Probe into Alleged Bribery at MISC - Offshore Energy. Offshore-Energy.Biz.

Faradi, M. A., \& Supriyanto, S. (2019). Faktor-Faktor Yang Mempengaruhi Peringkat Obligasi Pada Perusahaan Non Keuangan Yang Terdaftar Di Bursa Efek Indonesia. Jurnal Ekonomi Dan Bisnis, 2(1), 13. https://doi.org/10.35590/jeb.v2i1.703.

Givoly, D., Hayn, C. K., \& Katz, S. P. (2010). Does public ownership of equity improve earnings quality? Accounting Review, 85(1), 195-225. https://doi.org/10.2308/accr.2010.85.1.195.

Hartini, M. N. (2017). State-Owned Enterprises : a Comparison Between the UK, Japan, and Malaysia. International Journal of Economics, Commerce and Management, 5(2), 114130. http://ijecm.co.uk/wp-content/uploads/2017/02/526.pdf.

Hoang, T. C., Abeysekera, I., \& Ma, S. (2019). Earnings Quality and Corporate Social Disclosure: The Moderating Role of State and Foreign Ownership in Vietnamese Listed Firms. Emerging Markets Finance and Trade, 55(2), 272-288. 
https://doi.org/10.1080/1540496X.2018.1521801.

Hutapea, H. (2019). Pengaruh Good Corporate Governance dan Corporate Social Responsibility terhadap Nilai Perusahaan. Jurnal Informasi, Perpajakan, Akuntansi Dan Keuangan Publik, 4(2), https://doi.org/https://doi.org/10.30871/jaat.v4i1.913.

113-135.

Majiyebo, O. J., Okpanachi, J., Nyor, T., Adabenege, O., \& Ahmed, Y. (2018). Audit Committee Independence, Size and Financial Reporting Quality of Listed Deposit Money Banks In Nigeria. IOSR Journal of Business and Management (IOSR-JBM), 20(2), 40-47. https://doi.org/10.9790/487X-2002044047.

Malaymail. (2018). MISC to cooperate fully with MACC in bribery probe. https://www.malaymail.com/news/malaysia/2018/03/06/misc-to-cooperate-fullywith-macc-in-bribery-probe/1591731.

Mamun, M. A., Shaikh, J. M., \& Easmin, R. (2017). Corporate social responsibility disclosure in malaysian business. Academy of Strategic Management Journal, 16(2), 1-9. https://www.abacademies.org/articles/corporate-social-responsibility-disclosure-inmalaysian-business-6639.html.

Mohmed, A., Flynn, A., \& Grey, C. (2019). The link between CSR and earnings quality: evidence from Egypt. Journal of Accounting in Emerging Economies, 10(1), 1-20. https://doi.org/10.1108/JAEE-10-2018-0109.

Mousa, G. A., \& Desoky, A. (2019). The effect of dividend payments and firm's attributes on earnings quality: Empirical evidence from Egypt. Investment Management and Financial Innovations, 16(1), 14-29. https://doi.org/10.21511/imfi.16(1).2019.02.

Mulchandani, K., Mulchandani, K., \& Wasan, P. (2019). Dividends and Earnings Quality: Evidence from India. IIMB Management Review. https://doi.org/10.1016/j.iimb.2019.10.001.

Nguyen, T. T. N., \& Bui, P. K. (2019). Dividend policy and earnings quality in Vietnam. Journal of Asian Business and Economic Studies, 26(2), 301-312. https://doi.org/10.1108/jabes-07-2018-0047.

Obeng, V. A., Ahmed, K., \& Miglani, S. (2020). Integrated reporting and earnings quality: The moderating effect of agency costs. Pacific Basin Finance Journal, 60, 101285. https://doi.org/10.1016/j.pacfin.2020.101285.

Pathak, R., \& Ranajee. (2020). Earnings quality and corporate payout policy linkages: An Indian context. North American Journal of Economics and Finance, 51(July), 1-10. https://doi.org/10.1016/j.najef.2018.10.003.

Pricewaterhouse Coopers. (2018). Global Economic Crime and Fraud Survey 2018 (Malaysia Report). In Pwc (Vol. 2018, p. 30).

PrimtaSurbakti, L., BintiShaari, H., \& Bamahros, H. M. A. (2017). Effect of Audit Committee Expertise and Meeting on Earnings Quality in Indonesian Listed Companies: A Conceptual Approach. Journal of Accounting and Finance in Emerging Economies, 3(1), 47-54. https://doi.org/https://doi.org/10.26710/jafee.v3i1.97. 
Rezaee, Z., Dou, H., \& Zhang, H. (2019). Corporate social responsibility and earnings quality: Evidence from China. Global Finance Journal, January, 100473. https://doi.org/10.1016/j.gfj.2019.05.002.

Salehi, M., \& Bahrami, M. (2017). The e ff ect of internal control on earnings quality in Iran. 59(4), 534-546. https://doi.org/10.1108/IJLMA-02-2016-0012.

Samosir, H. E. . (2018). Pengaruh Faktor Keuangan Dan Komite Audit Terhadap Kualitas Laba. Jurnal Ilmiah Simantek ISSN: 2550-0414 Vol. 2, No. 1 Januari 2018, 2(2), 1-12. https://doi.org/10.1523/JNEUROSCI.0129-11.2011.

Scholar, S. (2015). [PDF] Malaysia company law_principles and practices _ Semantic Scholar. Semanticscholar.Org.

Siueia, T. T., \& Wang, J. (2019). The association between corporate social responsibility and earnings quality: Evidence from extractive industry. Revista de ContabilidadSpanish Accounting Review, 22(1), 112-121. https://doi.org/10.6018/rcsar.22.1.354361.

Sulastri, T., Adel, J. F., \& Manik, T. (2016). Pengaruh Ukuran Pembagian Dividen, Kenaikan Pembagian Dividen, Dan Persistensi Pembagian Dividen Terhadap Kualitas Laba Pada Perusahaan Manufaktur Yang Terdaftar Di Bursa Efek Indonesia Tahun 2014-2016. Repository Universitas Maritim Raja Ali Haji, 22(1), 1-17. http://repository.umrah.ac.id/1329/.

Surifah. (2010). Kualitas laba dan pengukurannya. Jurnal Ekonomi, Manajemen \& Akuntansi, 8(2), 31-47. https://surifah.files.wordpress.com/2013/08/surifah-2010kompetensi-kualitas-laba-dan-pengukurannya.pdf.

Wahyudin, A. (2015). Metodologi Penelitian (Penelitian Bisnis \& Pendidikan). Unnes Press.

Wulandari, S. (2018). Pengaruh Pertumbuhan Laba, Size, Leverage, Investment Opportunity Set, Dan Good Corporate Governance Terhadap Kualitas Laba. Universitas Muhammadiyah Surakarta. 